\title{
Studi of Environmental Optimum for Pearl Oyster (Pinctada maxima) Aquacuolture Using Marine GIS and Remote Sensing Case Study of Buleleng Regency, North Bali, Indonesia
}

\author{
Mohan Budiman ${ }^{\text {a*}}$, Takahiro Osawa b,c, I Wayan Arthana d \\ a Graduate Study of Environmental Sciences, Udayana University, Denpasar, Bali 80232, Indonesia \\ ${ }^{b}$ Graduate School of Science and Engineering, Yamaguchi University, Ube Shi Tokiwadai 2-16-1, 7550092, Japan \\ c Center for Remote Sensing and Ocean Sciences (CReSOS), Udayana University, PB Sudirman Street, Denpasar, \\ Bali 80232, Indonesia \\ ${ }^{d}$ Faculty of Marine and Fisheries, Udayana University, Bukit Jimbaran, Bali 80361, Indonesia \\ * Correspondence: mohan.budiman@gmail.com
}

Received: 1 September 2017; Accepted: 31 May 2018; Available online: 1 June 2018

\begin{abstract}
Oyster aquaculture is one of priorities for development and promotion of aquaculture activities in Buleleng Regency and since 2010 the production always increase and supports coastal communities. The selection of aquaculture structure system and farm site are importance. The selection should be based on an appraisal of the life history, habits, environmental parameters and socio-infrastructure. This study focused on obtaining the aquaculture structure system and site selection for Pearl Oyster (Pinctada maxima) in Buleleng Regency with seven attributes Chl-a, SST, bathymetry, and currents, distance to town, distance to pier, and distance to laboratory. The model structure for identifying culture structure and suitable sites for oyster aquaculture in coastal of Buleleng Regency was built on MCE (Multi Criteria Evaluation), the final result for suitable site outputs were compared with pearl production in Buleleng Regency in 2009, 2010, and 2011. The result of this study is that most areas at Buleleng coastal had medium suitability scores.
\end{abstract}

Keywords: Buleleng coastal areas; development of aquaculture; GIS based tool; pearl oyster; remote sensing data

\section{Introduction}

One of the Indonesian aquaculture business is increasing in pearl oyster farming of species Pinctada maxima. It is estimated that around 124,810 hectares of Indonesian equatorial seas provide suitable habitats for Pinctada maxima, the oysters producing the majestic pearls (Ministry of Trade of The Republic of Indonesia, 2010).

Bali is an island and province of Indonesia that is known as part of the coral triangle, the area with the highest biodiversity of marine species, in this Bali Province, pearl farms are located within the coastal of Buleleng Regency. Currently, oyster culture in Buleleng Regency is be one a potential investment opportunity, in 2010, the number of oyster culture produce is 42.5 tons.

The use of spatial planning tools such as Geographic information systems (GIS) and remote sensing for aquaculture can greatly help in the identification, analysis and possible allocation of specific geographical areas to be used aquaculture, particularly in those countries that have limited natural resources that are in high demand by competing users (FAO, 2013).

The objectives of this study are to identifying types of aquaculture structures system for pearl oyster (Pinctada maxima), to obtain Multi Criteria Evaluation (MCE) models by 
mapping and to find out suitable site for culturing Pinctada maxima. Results of this research are expected to be useful for development of pearl oyster industry by private or government, also determination of policies and strategies in Buleleng Regency.

\section{Materials and Methods}

The research location is at Coastal of Buleleng Regency, North Bali at position $8^{\circ} 3$ ' 40 $-8^{\circ} 23^{\prime} 00$ South Latitude and $114^{\circ} 25^{\prime} 55^{\prime \prime}-115^{\circ} 27^{\prime} 28^{\prime \prime}$ East Longitude (Figure 1). Buleleng Regency has favorable environmental conditions for aquaculture and is one of the most important aquaculture in Bali.

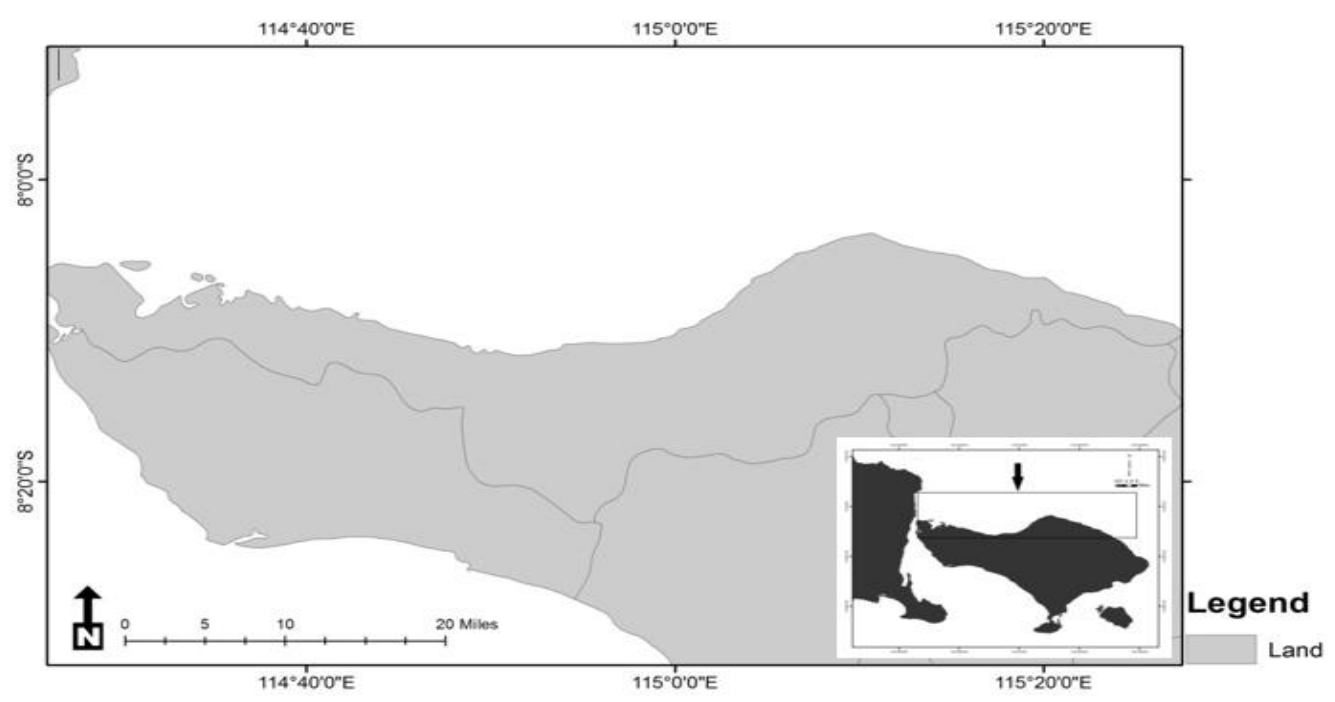

Figure 1. Research Location (Buleleng coastal areas)

The variables observed in this experiment includes environmental, and social infrastructural. Environmental aspect includes chlorophyll a, sea surface temperature, bathymetry, and currents, while socio-infrastructure aspect includes distance to town, distance to pier, and distance to laboratory. Monthly data of Chl-a from MODIS (Moderate Resolution Imaging Spectroradiometric)-Aqua Sensor in 2008-2010 with resolution 1.25 $\mathrm{km}$, monthly data of SST from AMSR-E (Advanced Microwave Scanning Radiometer for EOS) in 2008-2010 with resolution $1.47 \mathrm{~km}$, monthly data of current from Aviso in 20082009 with resolution $2.5 \mathrm{~km}$ and bathymetry from IBCAO (international Bathymetric Chart of the Arctic Ocean) in 2010 with resolution $4 \mathrm{~km}$. Distance to town and distance to laboratory from Bakosurtanal and distance to pier from Department of Marine and Fisheries Buleleng Regency. GIS used in this study were ArcGIS 10.1. It which used to perform the map lay out-making process. Global Mapper 12 is used to perform comfort data.

The analysis process of this study was reclassify the data from satellite imagery and field data, than it was grouped into three sub model namely environment (Chl-a, SST, Bathymetry, and currents), socio-infrastructure (distance to town, distance to pier, and distance to laboratory), and constrain (harbor). Reclassify adjusted with optimal suitability for pearl oyster aquaculture based on expert opinion and literature. Grouping of sub model in this study follow Nath et al. (2000) and Radiarta et al. (2008). The scoring system follow Pérez et al. (2003) where scores built from 1 until 8. The value of 1 is least suitable and 8 is most suitable. However value of 0 used as a constrain based on Radiarta et al. (2008). GIS tool for types of aquaculture structure not include in this analysis because of the factor is only one (Bathymetry). The schematic diagram of the suitable aquaculture site-selection and aquaculture structure system can be seen in figure 2 .

The model structure for identifying suitable sites for oyster aquaculture at Buleleng coastal areas was built based on hierarchical structures by Thomas Saaty (2008). While improvisation of model follow Radiarta et al. (2008) which weight of environment 0.6 and weight of socio-infrastructure 0.4 , weight of environment 0.4 and weight of socio- 
infrastructure 0.6 , we also built one improvisation which weight of environment 0.5 and weight of socio-infrastructure 0.5 . There are several pillars were used as the basis of analysis by Saaty and Vargas (2012) scale ratio, factors, rankings, scales, comparisons matrix, weight, check consistency from here Satty built equation which this equation will be used for overlay. $W_{j}$ is normalized of weight, $r_{i j}$ is attributes, rmax: sum of priority row* priority vector and $\mathrm{W}_{\mathrm{i}}$ is ratio scale.

$$
\text { Suitable site }=\sum_{j} \text { Wj } r i j=\gamma \max w i
$$

Radiarta et al. (2008) was built 17 points scale which starting from the less important $(1 / 9,1 / 8,1 / 7 \ldots 1 / 2)$ to most important $(1,2,3 \ldots 9)$ based on Malczewski (2000), Saaty (1999) also explain this theory. In this study use original fundamental scale of absolute numbers by Saaty (2008). Model verification was carried out by making comparisons between the suitable-sites model and pearl oyster production in Buleleng Regency in 2009, 2010, and 2011.
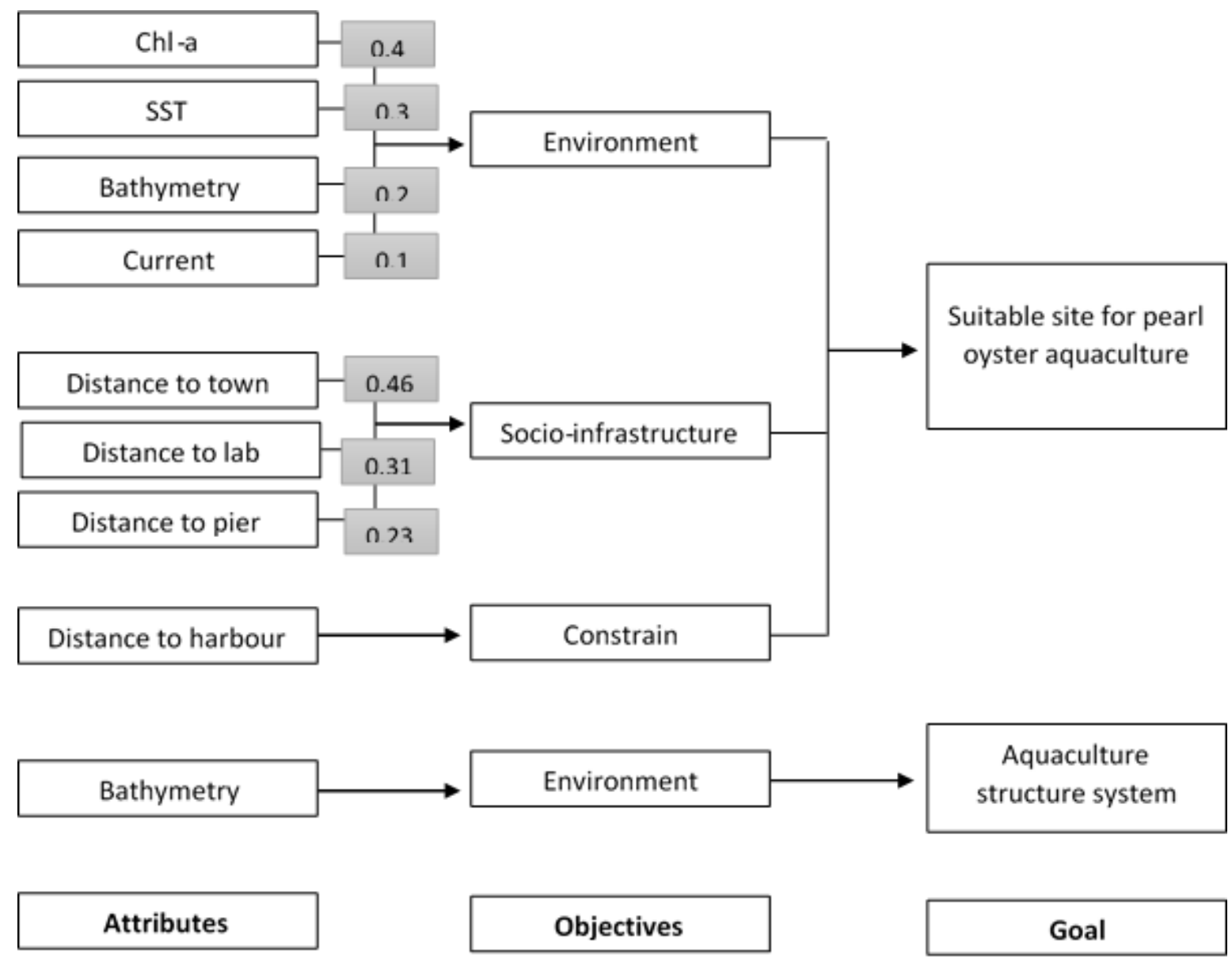

Figure 2. Schematic diagram of the suitable aquaculture site-selection and aquaculture structure system

\section{Results}

Different weight were applied for two sub model (environment and socio-infrastructure) to investigate how changing the weight of various factors affected the determination of the preferred area. Model 1 shows that most suitable area for oyster aquaculture in Gerogak and Kubutambahan which the percentage of suitability scores 8 is $25.3 \%$. Model 2 and model 3 also shows that most suitable area in Gerogak and Kubutambahan which the highest percentage (score 8 ) for model 2 is $21.5 \%$, and for model 3 (score 8 ) is $23.1 \%$ (Figure 6). In this study, types of aquaculture structures for pearl oyster (Pinctada maxima) by mapping (Figure 7) has been showed area at Coastal of Buleleng Regency suitable for loglines and raft. 


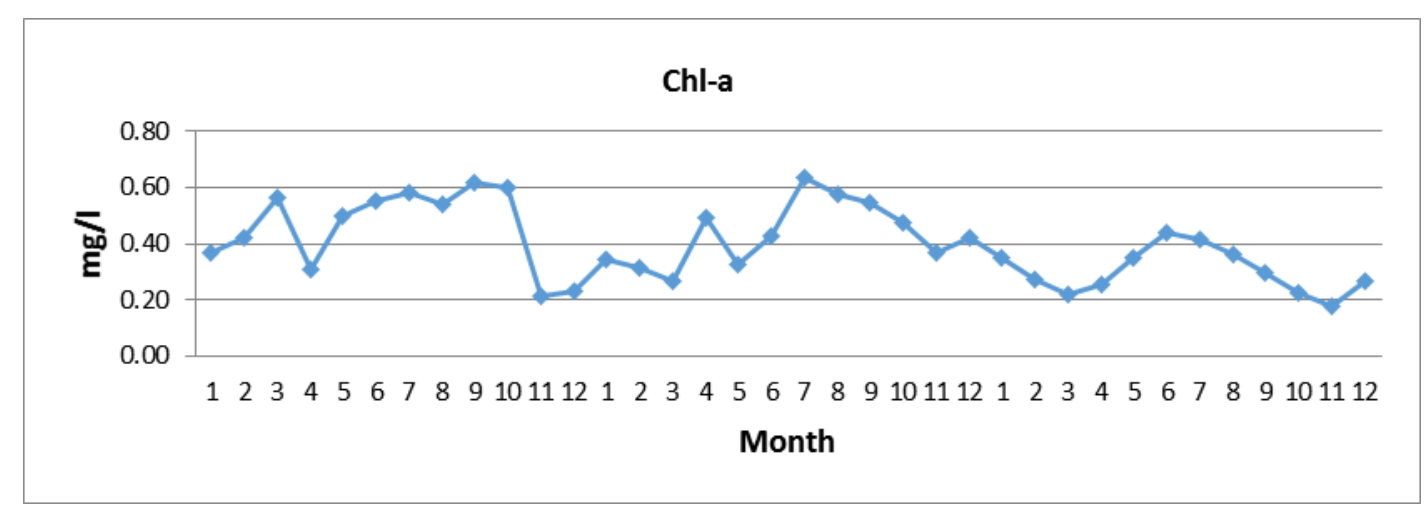

Figure 3. Chl-a consentration each month 2008-2010 in Buleleng Coast

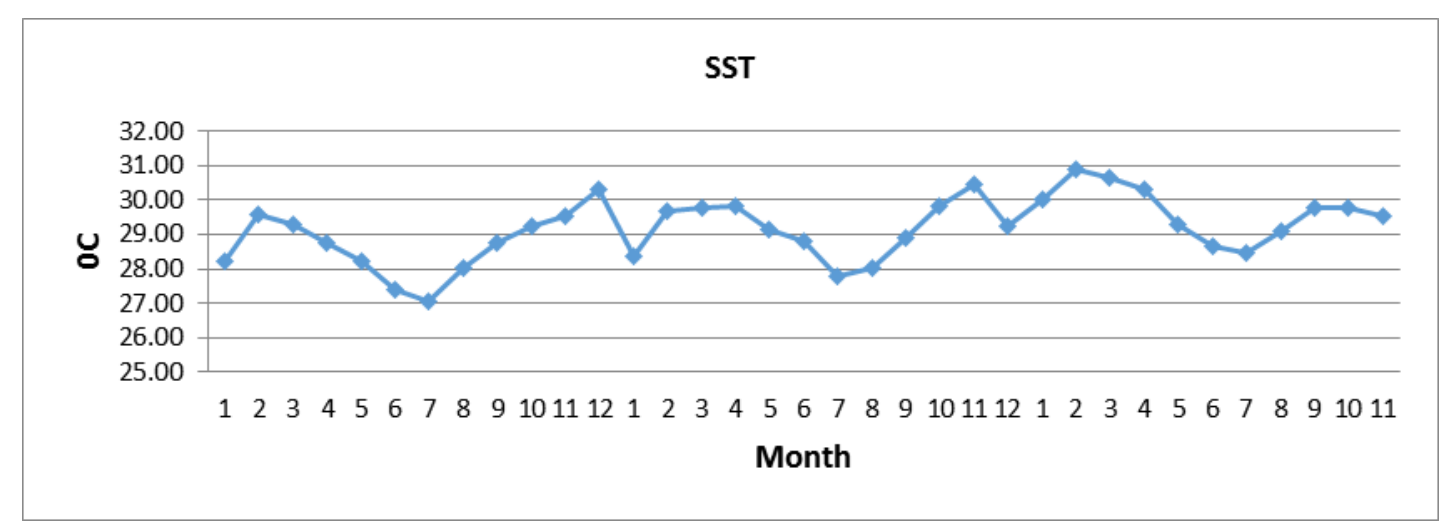

Figure 4. SST each month 2008-2010 in Buleleng Coast

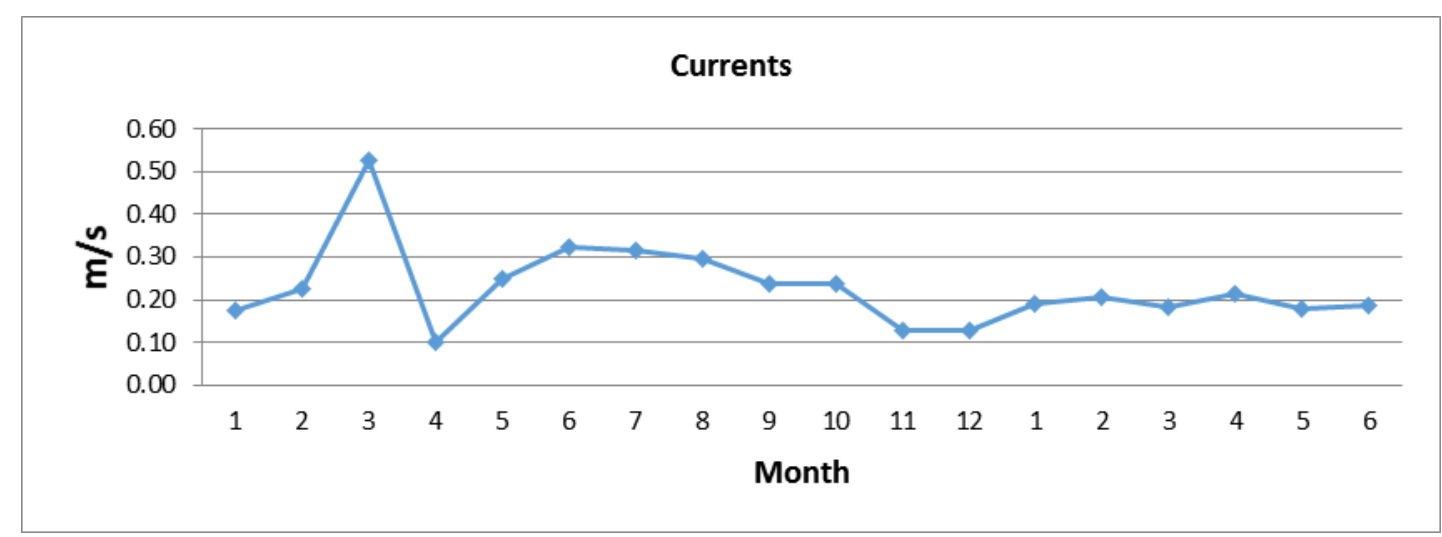

Figure 5. Currents speed each month 2008-2009 in Buleleng Coast

Suitable site of pearl oyster aquaculture obtained by verification with pearl oyster production each years, ranging from 2009 to 2011 . The closest model is model 1 which weight of socio-infrastructure more than biophysical. As a whole suitable scores are located at Gerogak and Kubutambahan, with percentage value of 25.3\% (Figure 6, score 8).

\section{Discussion}

The success of an aquaculture is dependent on many factors including the selection of a suitable site and types of aquaculture structures. According to Lal (2005), there are six basic types of aquaculture structures for oyster: Longlines system, raft system, rack system, onshore system, bottom system and underwaterplatform system. In this study, types of aquaculture structures for pearl oyster (Pinctada maxima) by mapping (Figure 4) has been showed area at Coastal of Buleleng Regency suitable for longline and raft.This based on Radiarta (2010) who mention that Pearl Oysters aquaculture with longline 
structure requires a depth of about 15-40 meters, Lal (2005), wrote that raft system is suitable for oyster farming in sheltered bay or in open areas and Radiarta and Saitoh (2009) mentioning that 60 meters as the maximum depth in order to minimize operation costs and difficulty in mooring (watercraft) systems and is as a constrain for types of aquaculture structure in this study. Pérez et al. (2003) discuss a constraint is a criterion which serves to limit the alternatives under consideration.
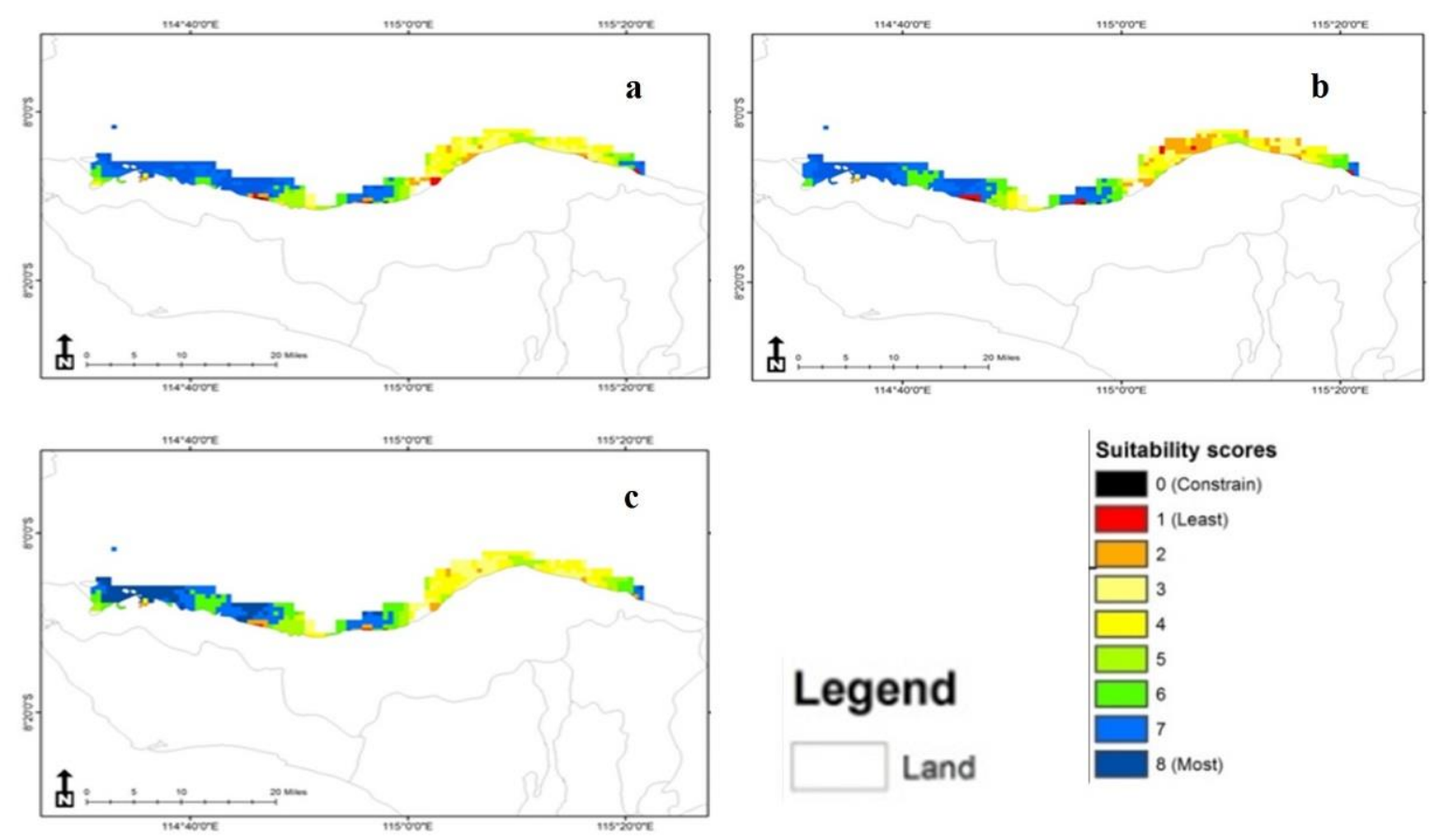

Figure 6. Suitability maps for models (a) Model 1 (b) Model 2 (c) Model 3

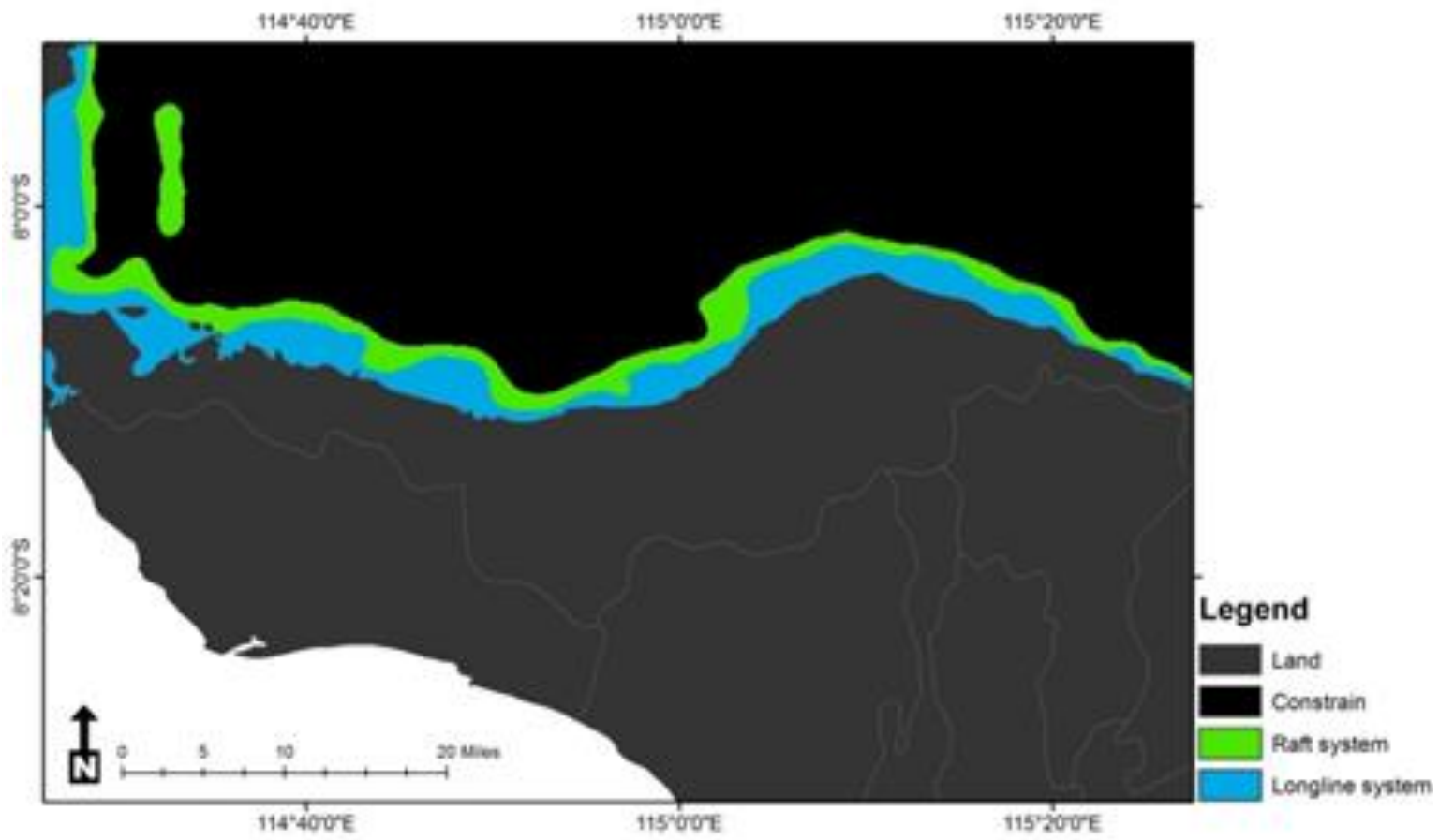

Figure 7. Aquaculture structure system 
Underwater platform and another structures not including in this study because these structure system is expensive to purchase and the energy costs for such installations are very high as well.

According Radiarta et al. (2008) the media of culture should not be in contact with the seabed to prevent predators such as starfish and crabs from feeding on the oyster. While the suitable area in Gerogak and Kubutambahan the media of culture are not contact with the seabed.

Current speed also must be considered in decision making for aquaculture structures because very strong currents may effect in damage of the structures, especially raft culture. Gervis and Sims (1992) write raft culture is best practiced in sheltered areas where wind and wave exposure is low. Currents at Coastal of Buleleng Regency not strong, in fact low, this can bee seen in figure 5.

Pearl oyster farmers at Coastal of Buleleng Regency usually make raft system for their cultivation. In raft system stocking density of cultivation higher than longline. This mean that the availability of nutrient should be high because pearl oyster is filter feeder and depend on natural food. Lacoste et al. (2014) discuss higher food availability illustrated by the high Chl-a concentration. At Coastal of Buleleng Regency Chl-a concentration not too high (Figure 3) from these data concluded that the stocking density for pearl oyster aquaculture at Coastal of Buleleng Regency especialy raft system should not too high for achieve maximum growth of Pinctada maxima.

The raft systems also have a bad impact on environment because maintenance activity in pearl oyster aquaculture occurred in pearl oyster aquaculture operation, this can cause pollution on ocean water, one of them is waste of biofouling.

One focus of this study is to obtain suitable site for pearl oyster aquaculture at Coastal of Buleleng Regency by three models with different weighting of each sub model. Nath et al. (2000) discuss ddetermining parameter weights is a crucial phase in the analysis. A slight change in weight coefficients can have a significant effect on the results of the suitability analysis. According to Haws (2002), Gervis and Sims (1994), and Mamangkey (2009) development of pearl oyster aquaculture is affected by many aspects, including environment (physical, biological, and chemical) and (Radiarta, 2010) socio-infrastructure factors.

Hamzah (2003) have studed about the effect of season on growth of Pearl Oyster. The result of his study on September, October, and November growth of Perl Oyster was low and on July the growth of Pearl Oyster was high. From satellite data (Figure 4) shows SST on July about $28^{\circ} \mathrm{C}$ this is optimal temperature for growth of Pearl Oyster while SST on September, October and November about $30^{\circ} \mathrm{C}$. Miguel et al. (1992) discuss temperature had a direct influence on growth with food concentration, but its increase caused a lower condition index, probably because of the higher energy requirement of the organisms at high temperatures. Bergh et al (2012) also discuss high fluctuation of water temperature cause bacteria and fungi is growing fast this can cause stress of Pearl Oyster so that decreased appetite which will eventually lead to mortality.

Feng and $\mathrm{Zu}(2012)$ explain when surface water is warm, cooler, nutrient-rich water is trapped below. In places where ocean currents cause upwelling, sea surface temperatures are often cooler than nearby waters, and chlorophyll concentrations are higher. In this study the relation of Chl-a consentration (Figure 3) and SST Figure 4 also shows the same thing which in July concentration of Chl-a higher than other season.

Although many study such as (Zhang., 2014) showed that the temperature, salinity, nutrients, and oxygen of seawater changed when El Niño/La Niña occurred, in this study showed high impact of this phenomenon in Chl-a concentration and currents (Figure 3 and Figure 5).

The result of GIS model could be verified using pearl oyster aquaculture production (i.e. Marine and Fisheries of Buleleng Regency 2009, 2010, and 2011). For example, figure 6 showed the highest score at Gerogak and Kubutambahan this appropriate with pearl oyster production. Guisan and Zimmermann (2000) discuss the use of the term verification when measuring the adequacy between model predictionsand field observations, what is called accuracyassessment in remote sensing studies. To analyze the predictive success of models this study follow Radiarta and Saitoh (2009). 
This study showed that model 1 (socio-infrastructure<environment) more good than model 2 and model 3, which $25.3 \%$ have 8 suitability scores and $22.5 \%$ have 7 suitability scores. Approximately $10.3 \%, 15.2 \%$, and $14.6 \%$ of potential area were classified as middle score 4, 5, and 6 (Figure 6).

\section{Conclusions}

The application of the developed Remote Sensing and GIS showed that it works effectively to identifying types of aquaculture structure system at Coastal of Buleleng Regency. MCE models showed that most of the areas at the Coastal of Buleleng had medium suitability scores. This study showed that remote sensing and GIS tool modelling by verification with aquaculture production in Buleleng Regency is a powerful tool for obtain suitability site of pearl oyster aquaculture.

\section{References}

Bergh, O., Asplin, L., Sandvik, A., Lorentzen, T., Sundby, S., Wergeland, H. (2012). Impact of climate change on the prospects for aquaculture. Bergen, Norway: Institute of marine research.

Meaden, G. J., \& Aguilar-Manjarrez, J. (2013). Advances in geographic information systems and remote sensing for fisheries and aquaculture. FAO Fisheries and Aquaculture Technical Paper, (552), I.

Feng J. F., L. Zu. 2012. Changeng trends and relationship between global ocean Chlorophyll and SST. Procedia Environment Science.

Feng, J. F., \& Zhu, L. (2012). Changing trends and relationship between global ocean chlorophyll and sea surface temperature. Procedia Environmental Sciences, 13, 626-631.

Gervis, M. H., \& Sims, N. A. (1992). The biology and culture of pearl oysters (Bivalvia pteriidae). London, England: Overseas Deveporment Adsministration.

Guisan, A., \& Zimmermann, N. E. (2000). Predictive habitat distribution models in ecology. Ecological modelling, 135(2-3), 147-186.

Haws, M. (2002). The basic methods of pearl farming: a layman's manual. Hawaii, USA: Center for Tropical and Subtropical Aquaculture.

Lacoste, E., Gueguen, Y., Le Moullac, G., Koua, M. S., \& Gaertner-Mazouni, N. (2014). Influence of farmed pearl oysters and associated biofouling communities on nutrient regeneration in lagoons of French Polynesia. Aquaculture Environment Interactions, 5(3), 209-219.

Lal, B. (2005). Applied zoology pearl culture. Varanasi, India: Department of zoology Banaras Hindu University.

Malczewski, J. (2000). On the use of weighted linear combination method in GIS: common and best practice approaches. Transactions in GIS, 4(1), 5-22.

Mamangkey, N. G. F. (2009). Improving the quality of pearls from Pinctada maxima. Dissertation. Queensland, Australia: School of Marine \& Tropical Biology, James Cook University.

Miguel, A., Re-Araujo, A. D., \& Voltolina, D. (1992). Growth of the pearl oyster Pteria sterna under different thermic and feeding conditions. Marine Ecology Progress Series, 89, 221-227.

Nath, S. S., Bolte, J. P., Ross, L. G., \& Aguilar-Manjarrez, J. (2000). Applications of geographical information systems (GIS) for spatial decision support in aquaculture. Aquacultural Engineering, 23(1-3), 233-278.

Pérez, O. M., Telfer, T. C., \& Ross, L. G. (2003). Use of GIS-based models for integrating and developing marine fish cages within the tourism industry in Tenerife (Canary Islands). Coastal Management, 31(4), 355-366.

Radiarta, I. N., Saitoh, S. I., \& Miyazono, A. (2008). GIS-based multi-criteria evaluation models for identifying suitable sites for Japanese scallop (Mizuhopecten yessoensis) aquaculture in Funka Bay, southwestern Hokkaido, Japan. Aquaculture, 284(1-4), 127-135.

Radiarta, I. N., \& Saitoh, S. I. (2009). Biophysical models for Japanese scallop, Mizuhopecten yessoensis, aquaculture site selection in Funka Bay, Hokkaido, Japan, using remotely sensed data and geographic information system. Aquaculture international, 17(5), 403.

Radiarta, I. N. (2010). Model spasial dengan Sistem Informasi Geografis (SIG) untuk penentuan lokasi potensial pengembangan budidaya tiram mutiara di Provinsi Papua Barat. Dalam Prosiding Seminar Nasional tahunan VII Hasil Penelitian Perikanan dan Kelautan,. Yogyakarta, Indonesia, 24 Juli 2010 (pp. 53)

Saaty, T. L. (1999). Basic theory of the analytic hierarchy process: How to make a decision. Revista De La Real Academia De Ciencias Exactas Físicas Y Naturales, 93(4), 395-423. 
Saaty, T. L. (2008). Decision making with the analytic hierarchy process. International journal of services sciences, $\mathbf{1}(1)$, 83-98.

Saaty, T. L., \& Vargas, L. G. (2012). The seven pillars of the analytic hierarchy process. Boston, USA: Springer.

(C) 2018 by the authors; licensee Udayana University, Indonesia. This article is an open access article distributed under the terms and conditions of the Creative Commons Attribution (CC-BY) license (http://creativecommons.org/licenses/by/4.0/). 